\title{
The Strengthening of Humanity Value in the Generation of Digital Natives in the Era of Digital Technology through Nawung Sekar Dance
}

\author{
Maria Denok ${ }^{1}$, M. Jazuli ${ }^{2}$, Tjetjep Rohindi ${ }^{3}$, Suminto ${ }^{4}$ \\ ${ }^{1,2,3}$ Art Education Departement, Faculity of Postgraduate, Universitas Negeri Semarang, Indonesia \\ ${ }^{4}$ Indonesian language and literature Departement, Faculity of Language and Art, Universitas Negeri \\ Yogyakarta \\ Corresponding email: mdenok14@gmail.com
}

\begin{abstract}
Presence of the generation of Digital Natives in Indonesia with all its existence is a manifestation of the existence of Indonesia as part of a world that is also experiencing growth technology. This situation has resulted in a cultural gap that arose as a result, shifting and changing the value of life. The purpose of this study convey the fact dance Nawung Sekar which became part of the dance tradition is able to teach humanity value to the generation of digital natives. This study uses an interdisciplinary approach with several studies of science such as: child development psychology, sociology, ethnology, the subject of his research is the children who learn dance Nawung Sekar in YPBSM Yogyakarta. Traditional art was the product of a generation of digital immigrants that have a life value humanity that shapes character, found the fact that Nawung Sekar dance as part of the art tradition can be used as a medium to pass on the humanity value to the generation of digital natives in the era of digital technology.
\end{abstract}

Keywords: Strengthening, Digital Technology, Nawung Sekar Dance

\section{Introduction}

In Indonesia the development of information technology since 2000 has increased rapidly, especially with the presence of mobile communication devices, online media, online games and web technology. Developed then several online social networking applications, such as: Facebook, Twitter, Instagram, Blogs, which makes users staying connected with various parts of communication devices such as iPhone, iPad, PC, Tablet, and so on.

According to several research results one of the existence of social networking since 2010 has become a life style of young people today (Riana, 2010). Now the information technology used by young people today become a necessity of life that animates their daily life. The dependence on technology conducted by children in the millennium era has had a positive and negative impact on the life of Indonesian people, especially on the sustainability of existing cultural traditions. The emergence of living connected life patterns, defined as a form of life that can penetrate space and time with only being in one place but able to connect with some people in the room and different times only through gadgets. The pattern gave rise to different social interactions from previous times; meaning that the interaction of individuals with other individuals should not be done face to face or face to face but through gadget devices. With the ease in accessing various media information and technology, causing children to be lazy to move and move. They prefer to sit still in front of gadgets and enjoy the world that is in the gadget. This certainly adversely affects the health and development of the child's body, especially the child's brain and psychological. In addition, too long to spend time in front of the gadget can also bring adverse effects to the social ability of children (Hohman, 1998). They are not interested in playing with peers because they are more interested in playing with their digital games. In addition, children are more difficult to concentrate in the real world because they are accustomed to living in a digital world that gives little error or destruction (Yee, 2014).

The existence of technology that cannot be avoided raises the dichotomy of people living and developing in the current era of technology. society is divided into 2 types of generation that is the generation of Digital Immigrant and generation of Digital Natives. The meant by the generation of Digital Immigrant is a living and surviving society in the digital age so as to make an effort to adjust to the technological sophistication. While the generation of Digital Natives to call the generation that was born, lived and developed in the digital era with the use of technology as part of life. In Indonesia the generation of Digital Natives is a generation classified in the age group $\leq 25$ years in 2010 . 
From some of the explanations about the existence of children living in the Digital era found the fundamental thing that their dependence on technology was able to close space for the social interaction between one individual and the other with face to face and the increasingly disinterested forms of nonintersecting traditional activities with technology. It closes the space for traditional arts that are unacceptable to the technology for young children, so the presence of early childhood learns traditional culture into an interesting phenomenon.

The form of phenomenon that researchers found in one of the traditional dance studio in Yogyakarta city that the participants of children aged 3-16 years who still want to practice dance classical dance Yogyakarta, the studio is located in Ndalem Pudjokusuma, it name is YPBSM Yogyakarta. The data the researchers get through the results of observations and interviews for \pm 2 year (March 2015 November 2017).

This study aims to make the cultural gap between the generation of digital immigrant and the generation of digital natives can be bridged for the existence of life alignment in the era of this technology.

\section{Methods}

This research uses interdisciplinary research approach. Such interdisciplinary approaches include: child development psychology, sociology, ethnology, through several approaches the author examines and analyzes the issues raised in this study.

Approach to developmental psychology of children to describe and analyze children of the generation of Digital Natives as part of humans who have basic needs for growth and development. This approach is also used to understand the nature and needs of the child, so as to know what characters can be formed and raised.

The research design used is qualitative research method with phenomenology research design, It is realized that the exploration of possible cultural shifts emerges as a part to be revealed, the phenomenon found in this research is the emergence of cultural situation between digital children natively with the Javanese as a buffer classical dance style Yogyakarta (Maria, 2016).

Next uses the ethnographic method, arguing that this study is related to "a long- standing group that has developed the same values, beliefs, and language and then the ethnographic design is a qualitative research procedure for describing, analysing and interpreting similar patterns of behavior, belief and language in a culture-sharing group, with time so Ethnographic approach is used to understand the situation of Nawung Sekar dance support community (Cresswell, 2015).

\section{Results and Discussion}

Education according to $\mathrm{Ki}$ Hajar Dewantara has the ultimate goal to make human beings as noble beings; meaning that all forms of education have the duty and responsibility to make learners as beings who have values and noble character (Dewantara, 1977). Educational process can be done in various ways both formally and non-formal, while the substance studied can also vary according to the needs of the community. Children as part of a community member are required to learn the value that exists in the community where the child is growing and developing. The research design used is qualitative research method with phenomenology research design, which says that qualitative research can be used to get elaborate details about phenomena such as feelings, thought processes, and emotions that are difficult to extract or learn through more conventional methods (Corbin, 1998). Because it is realized that the exploration of possible cultural shifts emerged as a part that must be revealed, the phenomenon found in this research is the emergence of cultural situation between digital children natively with the Javanese as a buffer classical dance style Yogyakarta.

Alwisol defines character as a description of the behavior performed by individuals by highlighting both explicit and implicit values. Alwisol's statement gives an understanding that an individual must recognize and understand the values that exist in order to form a character (Alwisol, 2009). While the value from Higgard and Marquis an element that shapes the personality of the individual, Value is formed as a result of social stimulation and ability to present themselves well, it can be taken a conclusion that to introduce the value of character forming should be done since an early age.

Some research results show that early childhood has the ability to absorb and learn with maximum through the stimulation 
provided correctly by those around him. The environment in which the child lives and develops is an inseparable part in shaping the character of the child.

The existence of technology is inevitable in this millennium, the era where technological devices become an important part of human life. In Indonesia the development of information technology has increased rapidly since 2000 , it is marked by the presence of mobile communication devices, online media, online games and web technologies that can be uploaded and downloaded easily by the community.

The popularity of technological devices among the community is evolving into a social communication container, namely the emergence of several online social networking applications, such as: Facebook, Twitter, Myspace, Blogs; which makes users staying connected with various parts of communication devices such as blackberry, iPhone, iPad, PC, Tablet, and so forth (Riana, 2010).

The existence of social networking since 2010 has become life style of young people today. Riana further said that the information technology used by young people today become a necessity of life that animates their daily life.

The dependence on technology done by the children in the millennium era has had a positive and negative impact on the life of Indonesian people, the positive impact felt by the people of Indonesia is 1) Facilitating communication between one individual and another; 2) Provide easy access to information; 3) Make it easier to disseminate information; 4) Facilitate the movement of human beings to access information about the specific needs required by individual users. It brings up the living connected life pattern, defined as a form of life that can penetrate space and time by only being in one place but being able to connect with multiple people in different places and only through gadgets so that the necessities of life can be solved quickly and easily.

The emergence of these positive impacts coupled with the adverse negative impacts on the sustainability of traditional culture that already existed. The pattern gave rise to different social interactions from previous times; meaning that the interaction of individuals with other individuals should not be done face to face or face to face but through gadget devices. With the ease in accessing various media information and technology, causing children to be lazy to move and move. They prefer to sit still in front of gadgets and enjoy the world that is in the gadget.

This is certainly bad for the health and development of children also adversely affects the psychological child. In addition, too long to spend time in front of the gadget can also bring adverse effects to the social ability of children's emotions. They become uninterested in playing with their peers because they are more interested in playing with their digital games, the more it becomes more difficult for children to concentrate in the real world because they are accustomed to living in a digital world that gives little error or destruction (Yee, 2014).

Some of the above explanations suggest that on the other hand technological advances have the potential to encourage children to forge weak relationships between human beings with each other in the real world. The time that should be used for mingling and interacting directly diminishes because the time is consumed just to enjoy it all in solitude. Even some forms of play are played individually, causing smaller scope of extensive relationships.

The results of observations and interviews conducted by researchers from March 2015 until November 2016 found that the classical dance style of Yogyakarta is still continuously trained in Pujokusuma palace on Tuesday and Thursday at: $16: 00$ to $18: 30$; with an average number of participants of 40-60 children per exercise; with an age range of 3-16 years. Children learn according to their abilities, that is, adjust their dancing skills. Children who practice are divided into 4 categories for girls and boys from school-age children, or kindergartens up to 3rd graders (junior high) and high school.

The existence of these children became an interesting event according to the researchers because the learning process conducted in the dance studio Foundation Pamulangan Beksa Sasminta Mardawa using a conventional form of learning that is the method of demonstration (imitating from the teacher) and few use of technology equipment, just as a player. And for each class is given time to practice for \pm 60 minutes / 1 hour, but it appears that the children are concentrating on the stages taught by the teacher.

To be able to focus more on this research problem is limited to 1 dance subject in beginner / early class that study dance Nawung 
Sekar with participants of children aged 3-8 years. The reason is Nawung Sekar dance is a dance initiated by Rama Sasmita with the initial idea to create a dance that makes children ready to dance Sari Kusuma (interview with Ibu Angela Retno Nooryastuti S.Sn.). Rama Sasminta further said that this dance should be cheerful so that children are willing and able to learn Yogyakarta classical dance.

Yogyakarta classical dance is a dance that has some rules, values and certain characters that are closely related to the cultural, social and cultural tradition of Yogyakarta. Yogyakarta classical dance has the characteristics of inspiration Sawiji, Greget, Sengguh, Ora mingkuh. Nawung Sekar dance is created with all the standard rules contained in the classical dance style of Yogyakarta, but on the other hand this dance was created also with attention to the needs of children.

Inheritance is a means used to inherit the system, patterns, rules, traits, values, education, skills and many things from previous generations to the next generation; Even the process of inheritance done by previous generations to the next generation is becoming

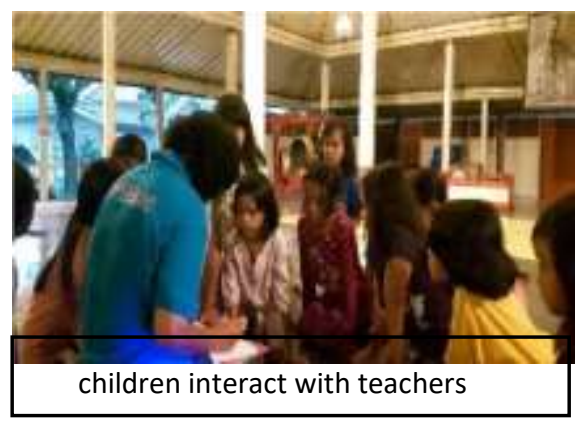

a part of the way to perpetuate the existence of a society (Hauser, 1974).

Further in culture there are 3 important things to be able to perpetuate culture that is by: 1) Culture is transferred from one generation to the next, as a legacy or social tradition; meaning that there is a process of inheritance done by generations previously consciously done to preserve existing culture in order to continue to exist in the next generation. 2) Culture studied is not genetically derived; there is a conscious effort to study the results of culture (cultural products, such as: the arts) in formal and nonformal institutions. 3) Culture is shared and shared by the community; can be interpreted that the existing culture is a guide in life together where the culture is created and developed.

These three processes imply that the means used to divert culture as a system through the educational process. This educational process has the goal of sustaining the value that a generation of the next generation wants to pass on or be inherited by the next generation as a cultural identity of the community.

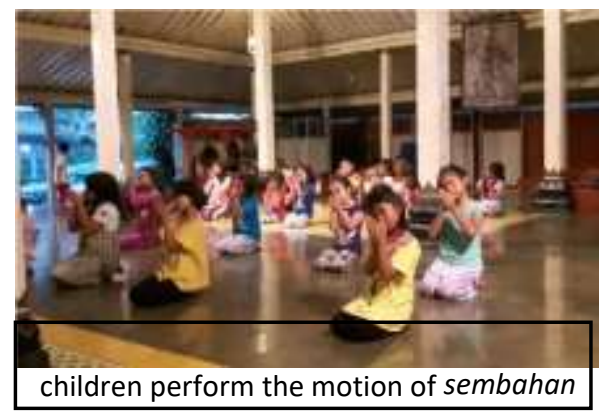

Figure 1. Learning process of Nawung Sekar dance in YPBSM

In this study the researchers found that there is a process of inheriting the value of Javanese tradition, especially Yogyakarta to the early childhood as a next generation of previous generations through the process of learning Nawung Sekar dance performed in YPBSM. As for some of the inherited values are:

\subsection{Sawiji,}

Sawiji which means the total concentration realized in the smoothness (coherence) in dancing (without mental disorder). Appears as a child begins to learn a dance and performs it within a period of \pm 5 months in order to level up to the next grade. Further concentration arises when children should dance while the environment / place where they are open, causing trouble for concentration.

Concentration demands also arise in the teaching and learning process, the method used in dance learning in YPBSM studio is imitation method. This method requires more attention due to the coordination of movement with the eye to see the teacher and ears to listen to music.

\subsection{Greget}

Greget is the dynamics or spirit of the soul (inner dynamic) but greget must be interpreted and done with a self-control to not lead to rudeness (without being coarse). This attitude arises when the child learns to control the power for every movement that is danced. Actually not something that is easy because children 
especially at an early age are in a moody situation in the development stage. Then this opportunity is a good opportunity to properly stimulate the child's self-control.

\subsection{Sengguh}

Sengguh which has the meaning of selfconfidence (self-confidence), but confident that does not lead to arrogance or arrogance (without being arrogant). Through the process of learning Nawung Sekar dance is found the fact that children are able to increase their selfconfidence, appear on the show they move dancing at certain times without imitating the teacher and witnessed by the introduction (parents, guardians, visitors and even tourists).

\subsection{Ora mingkuh}

Ora mingkuh who means to have a strong will, full of responsibility and abstinence (noretreat) as an effort to build self-discipline

This fact arises from their presence / children following the training process until the exam even goes up level by learning new dance. Further demonstrated by the performances that use the costume and makeup Nawung Sekar dance which is certainly not as comfortable as everyday costume but they are required to be able to dance well.

\section{Conclusion}

Traditional art was the product of a generation of digital immigrants that have a life value humanity that shapes character, found the fact that Nawung Sekar dance as part of the art tradition can be used as a medium to pass on the humanity value to the generation of digital natives in the era of digital technology.

\section{References}

Alwisol 2009 Psikologi kepribadian

Corbin, Strauss 1998 Grounded Theory Research

Creswell, Jhon W. 2015. Penelitian Kualitatif dan Desain Riset. Yogyakarta:Pustaka Pelajar

Denok Maria. 2016. Sembada 41

Dewantara Ki Hajar 1977 Karja

Hauser Arnold 1974 The Sociology of Art

Hohman, C. 1998 Journal Child Care Information Exchange 12360

Jin Shin Yee. 2014. Mendidik Anak Di Era Digital

Mark Evan Nelson. 2012. Language Learning \& Technology. 163 Pp 35-39

Riana, Deny. 2010. Ensiklopedia Seni-Budaya Cabang Seni. Jakarta: Trias Yoga Kreasindo 